\title{
The Role of Measuring in the Learning of Environmental Occupations and Some Aspects of Environmental Methodology
}

\author{
Lükő István \\ Faculty of Adult Education and Human Resources Development, University of Pecs, Hungary
}

Copyright $(\mathrm{C} 2016$ by authors, all rights reserved. Authors agree that this article remains permanently open access under the terms of the Creative Commons Attribution License 4.0 International License

\begin{abstract}
The Methodology neglected area of pedagogy, within the environmental specialist teaching methodology cultivating the best part is incomplete. In this article I shall attempt to environmental Methodology presented in one part of the University of West Environmental Education workshop, based on the measurement of experiential learning as an important activity and a specific description of the doctoral dissertation. The research aims to explore secondary vocational learning environment's role in the measurement of the textbook use, knowledge and use of the instrument, and analysis methods used in the classroom. The results of these studies are: 1 . The digital versatile bag clearly helps the students prepare the measurements. 2 . Interviewed schools teachers measuring suitcases field is used the most, which fits into the curriculum and the requirements as well. 3 . The topic of measurements than the theoretical structure and operating principle of making instruments also differ - teachers. 4. Mainly in this area can be a very good use of the so-called moving figure method. To sum up, the conclusion is an important work of environmental art measurement that specifies the use of modern ICT-based, interactive methods of theoretical and practical skills development.
\end{abstract}

Keywords World Bank Programme, Measuring as Student's and Teacher's Activity, Enhancing the Measuring Skill, Visualization of Curricular Content

\section{Introduction}

\subsection{The Environmental Pedagogy Workshop of the NYME ${ }^{1}$}

\subsubsection{The World Bank Programme and Its Results}

1 NYME= Nyugat-Magyarországi Egyetem, University of West Hungary
The renewal of the training of vocational teachers has always been an important aspect and interest. [1] Such a possibility was the period between 1994 and 1997, when, among educational reforms and developments, an international development programme was implemented within the framework of renewing the content and methodology of primary and secondary education and vocational training, closely linked to the development of vocational training schools. The Youth and Vocational Teacher Training subprogrammes were running parallel to the Human Resources Development Credit project of the World Bank with foreign credit and professional support, the curriculum and the methodology were developed, as it were, synchronously.

The essence of the World Bank Model was to focus on the practice-oriented attitude and the modularization of the curriculum. It left more scope to the scientific preparatory subjects and the generally educational subjects/scopes of knowledge as well as the developing effects forming the behaviour. The vocational teachers were prepared to these ways of developing the abilities and modern methods, basing on the use of a considerable system of means. Both secondary school teachers and those in higher education were assisted with exchanges of experience and consultative developing activities. [2]

The syllabi were characterized by a curriculum attitude, their structure being differentiated according to the groups of occupations. Thus, the training of vocational teachers was also composed of a country-wide/central structural module, one for the group of occupations and a local/school-level one.

If we regard it that way, these formed modular structures within each group of occupations. The general curricular characteristics of the training were analysed in detail by Dr. Gubán Gyula. [3] The local syllabi of the development for the specific group of occupations were prepared by each university or college, also in a modular structure. In each group of occupations, the schools got instruments and educational technology equipment worth 100,000 to 400,000 
USD. For the teacher training in the group of occupations in environmental protection and water economics, computers, environmental measuring instruments, measurement kits and software, worth about 132,000 USD, arrived in Sopron. In this way, an accredited Multimedia and Environmental Methodology Laboratory came into existence in the Teacher Training Institute of the University of Forestry and Wood Industry. The instruments and appliances in the laboratory serve as a basis for the methodological and didactical subjects in the training of engineer-teachers and vocational teachers in higher education.

An internal transformation of the Institute also followed this continuous development, and so, the Technology and Environmental Pedagogy Department was established in 1997. The laboratory, which belonged to the department but had professional and organisational autonomy, served primarily the teaching of the subjects called methodology, laboratory didactics, the methodology of practice, theory of education, environmental ergonomics and occupational orientation in the training of engineer-teachers and vocational teachers of technical jobs.

Besides the installation of the instruments on the spot and their integration into the pedagogical process, it also required local pedagogical development activity. [4], [5]

\subsubsection{Research Projects}

The workshop character of the Institute was formed, besides the above-mentioned developments, by research projects, which included making the syllabi greener, exploring the social background of the training of environmental professionals, the investigation of environmental textbooks, and, further, the study of the relationship of environmental culture, object culture and design. [6]

\subsubsection{Further Education for Teachers}

We have gathered our most important further education courses for teachers in Table 1.

\subsection{The Connections of the Methodology of Vocational Training}

Methodology as a subject takes the students' professional grounding into consideration and conveys the knowledge and enhances the skills with the help of which they perform the treatment (teaching and guiding the learning) of the various theoretical subjects at the given type of school. The preceding pedagogical and psychological knowledge is synthetised here, during the studies of environmental pedagogy. Thus, it is based on the subjects of general, personalistic, developmental, social and work psychology, historical and theoretical pedagogy, and didactics, and, further, it is also linked to the subjects called educational technology and pedagogical practice. Besides the system of subjects, the connections of methodology include the system of sciences and practical vocational and pedagogical activities.

Table 1. The most important further education courses for environmental teachers of the Teacher Training Institute of the NYME

\begin{tabular}{|c|c|c|c|}
\hline $\begin{array}{c}\text { Man and his environment Professional further } \\
\text { education course for teachers }\end{array}$ & $\mathrm{NSZI}^{2}-\mathrm{EFE}$ & Sopron-Sarród & June 1992 \\
\hline $\begin{array}{l}\text { PHARE Environmental education Further education } \\
\text { course for teachers Sopron Workshop }\end{array}$ & NYME- FHNP ${ }^{3}$ & & 1994-1996 \\
\hline World Bank Project Closing Conference & EFE-MÜM ${ }^{4}$ & Sopron & 1997 \\
\hline $\begin{array}{l}\text { Environmental Further Education for Teachers } \\
\text { COMENIUS Sokrates FHNP }\end{array}$ & & Sopron- Sarród & 1999 \\
\hline $\begin{array}{l}\text { Using science for the training and further education of } \\
\text { teachers of technics and ecology Conference in the } \\
\text { Month of science }\end{array}$ & $\begin{array}{c}\text { Working Committee for } \\
\text { Environmental Pedagogy } \\
\text { of the NYME FMK } \\
\text { TI-VEAB }\end{array}$ & Sopron & December 2006 \\
\hline $\begin{array}{c}\text { Modular Training Package Study Tour ILO Roas Iraq } \\
\text { West-Hungarian University }\end{array}$ & $\begin{array}{l}\text { University of West } \\
\text { Hungary- ILO- ROAS }\end{array}$ & Sopron & $18-27^{\text {th }}$ August 2005 \\
\hline
\end{tabular}

2 NSZI Nemzeti Szakképzési Intézet, National Institute for Vocational Training

3 FHNP=Fertö-Hanság Nemzeti Park, Fertö-Hanság National Park

4 MÜM=Munkaügyi Minisztérium, Ministry of Labour

5 MTA VEAB=Magyar Tudományos Akadémia Veszprémi Akadémiai Bizottsága, Hungarian Academy of Sciences, Academic Committee in Veszprém 
'Through its nature, Vocational Methodology is closely linked to the sciences, or, knowledge of the given vocation, which they acquired during their college/university studies, or which is taught in a "reduced"/transformed form at vocational schools. Thus, Vocational Methodology is a subject including content areas resting on several pillars in vocational teacher training.' [7]

This structure is shown in Table 2.

Table 2. The content connections of methodology

\begin{tabular}{|c|c|}
\hline Content & $\begin{array}{c}\text { Required level } \\
\text { of command }\end{array}$ \\
\hline $\begin{array}{c}\text { 1.Vocational knowledge } \\
\text { 1.1, Theoretical and practical knowledge of sciences } \\
\text { 1.2, Vocational knowledge in the form of subjects to } \\
\text { teach }\end{array}$ & $\begin{array}{c}\text { high level } \\
\text { medium level }\end{array}$ \\
$\begin{array}{c}\text { 2,Pedagogical, psychological basics } \\
\text { h, Knowledge and skills of conveying, the "how" } \\
\text { (method) }\end{array}$ & $\begin{array}{c}\text { high level } \\
\text { high level }\end{array}$ \\
\hline
\end{tabular}

\subsection{The System of Environmental Vocational Training}

The environmental vocational training was started a few decades ago in Hungary, first in the postgraduate form of higher education, primarily in the training of specialist engineers. [8] However, organised secondary education according to a standardised qualification register has been going on only according to the National Qualification Register (Országos Képzési Jegyzék, henceforth OKJ) issued in 1993. In this training, regulated by new laws, the subjects of vocational training schools and vocational secondary schools were distributed according to a completely new group of occupations in the OKJ.

An analysis of the syllabi and requirements of an environmental technician determined in the OKJ is indispensable during the research, because the proportion of theoretical and practical lessons as well as the areas of competence determine the direction, the tasks and topics of vocational methodology.

The currently valid OKJ includes a total of 11 qualifications in environmental protection and water economics on 3 qualification levels. These are, just to list them: sewer operator, public bath mechanic, waste buyer, wasteyard operator, environmental technician, municipal environmental technician, nature conservation and environmental technician, water and waste water technologist, water damage averter, waterworks operator, water conservation technician. One of these is the environmental technician with the level code 54. During the analytical inquiry into the educational documents, it was found that the Central Programmes and the $\mathrm{SZVK}^{6}$, based on the new OKJ, introduced in 2006, were created on the basis of the module system and the competence principle. The elaboration of the local-level documents is still in progress due to the central documents of the environmental

6 SZVK=Szakmai és Vizsga Követelmények, Vocational and Examination Requirements qualifications having been issued relatively late.

The inquiry into the framework curricula yielded the following results. This document arranges the objectives and tasks, and the requirements to be developed and divides them into the phases of orientation, preparatory education for the group of occupations and vocational training.

The preparatory education for the group of occupations includes 148 lessons of theory and 148 lessons of practice in the $11^{\text {th }}$ class, and 128 lessons of theory and 128 lessons of practice in the $12^{\text {th }}$ class. These are mostly students' activities related to measuring, during which the following curricular contents are dealt with. The principle and practice of water qualification, measurement of vibrations, basic measurement of radiation, measurement of precipitation, measurement of hydrographical data, physical procedures, examination of environmental elements.

When we were inquiring into the document Vocational and Examination Requirements, four branches of the environmental technician were focused on, in accordance with the new OKJ. The structure of the Requirement module describes the requirements of all branches, divided into the main chapters Task Profile, Quality Profile and Examination Requirements. Within the Task Profile, we concentrate on the field related to measuring, which includes the following elements concerning the students' activities:

- Measures and evaluates physical characteristics

- Measures and evaluates chemical characteristics

- Measures and evaluates biological characteristics

- Conducts radiological measurements

- Conducts meteorological measurements

- Conducts noise measurements

In the Quality Profile, the curricular contents (what?) are accompanied by requirement levels (on what level?) in the form of letters and numbers. So, e.g. (my selection)

- In vocational knowledge:

- On-the-spot (field) examination method (Level B)

- Chemical analysis (B)

- $\quad$ Noise measurements (C)

- In vocational skills:

- $\quad$ Use of measuring instruments and tools (5)

- In personal competence:

- Accuracy

- In methodical competence:

- Ability to evaluate.

\subsection{The Measurements Learning and Inquiry-based Learning Theoretical Basics in Brief}

The good nature and environmental sciences practice includes research-based skills and abilities, such as the design of the experiment; analyze, evaluate and critique the data and facts; modeling and drawing conclusions based on the facts.

In general, the research ('inquiry') can be defined in several ways, such as scientific truth, the pursuit of 
information or knowledge.

According to Colburn [9], a research-based teaching requires the development of a classroom where students are connected to a substantially open, student-centered, tangible ('handson') actions down.

According to Exline [10] with the traditional approach to content knowledge learning things learning ( 'learning about things, and less attention to developing the skills, things are learning (' learning things') attitudes care research.

The research-based learning methods include inductive approach Prince and Felder [11], because the process of learning a new experience, cases of a specific starting point, and it happens to more general conclusions, deduction of regularities. However, in practice neither teaching nor learning is never a purely inductive or deductive.

The tests / experiments at the beginning of the learning process rather inductive learning, teaching implement, and after the development of appropriate skills for the deductive method. Intricate and complex environmental diagnostic measurements and teach students solve problems inductive research-based learning methods.

\section{The Subject Matter and Methods of the Research}

\subsection{Inquiry into the Methods of Measuring as Students' Activity}

\subsubsection{The Pedagogical Characteristics of Measuring}

On the one hand, it can be stated that measurements and experiments conducted by students can be regarded as a particular empirical form of learning, in which the active participation is an effective knowledge-producing "method". Today we already know through research that, during formal learning at school, measuring can be a source of knowledge and, through practising, the means of verification and that of enhancing the measuring skills and, in a later phase, the means of diagnostic activity. The laboratory is a special classroom, which has the following didactic features: not only the surroundings, but also the furniture, the presence of the tools and instruments are a precondition of the learning environment characteristic of the given occupation. The measuring instruments accomplish the functions of acquiring knowledge and applying it (practising) individually or in small groups. All these often include also the methods of learning cooperatively, in groups. It is an important didactic issue what and how to evaluate during laboratory or diagnostic measurements. Based on the literature and experience, it can be stated that teachers evaluate the students' theoretical knowledge about the measurement and the instrument, their activity during measuring, as well as the form and content of the written or other archiving documents, that is, the measuring report. [12]

Today's ICT development has created the possibility of mobile teaching and learning, and the spreading of multimedia and its application also in didactic methods. [13] and [14] a result of that is the educational technology as an aspect of the methodology of environmental measurements. The devices of ICT, the measuring instruments, the interfaces, the complements as well as the tools, devices and localities of the quantity to be measured give the learning and the student's activity a technological character in the succession of the pedagogical process. In environmental education, interactive multimedia ICT devices can be used for lectures, demonstrations, cooperative learning, individually tailored and project tasks, reports and evaluation. An excellent example of network learning is the European and Hungarian network that measures the acidity of precipitation and GREEN,BISEL and the pollution of rivers. [15]

In today's schools, the learning forms according to the principles of conventional didactics and the new, modern ones - primarily supported by ICT - coexist. Therefore, it can be called - on the basis of Lükö István's terminology 'integrated learning technology' in the field of environmental education, which includes:

- 'Traditional, demonstrating-experimenting in the classroom

- Interactive, multimedia activities of a class or a group with computers in the classroom or in the laboratory with instruments

- Fieldwork with 'traditional' observations, dealing with natural indicators and their experiences

- Fieldwork with instrumental examination, data collection, evaluation on the spot or in the laboratory'. [16]

The person conducting the measurement is an important aspect. On the basis of that, we distinguish teacher's or demonstrational measurements and student's measurements.

In the phase 'source of knowledge', the data obtained from the measurements and the conclusions that can be reached on the basis of them accomplish primarily the development of thinking and empirical learning through the inductive method. 
Table 3. The main competence areas of environmental measurements

\begin{tabular}{|l|l|l|}
\hline Environmental element/area (What is measured?) & M & Competence areas to achieve \\
Soil protection & E & application of instrument \\
Water protection & A & skills development \\
Air protection & S & expertise \\
Wildlife protection & U & attention, concentration \\
Radiation protection & R & ability to evaluate \\
Noise and vibration protection & I & being unambiguous \\
Protection against pollution & N & accuracy \\
Waste management & G & capacity to obtain an overview \\
\hline
\end{tabular}

The most frequent form of this phase is the teacher's demonstrational measurement but, in a separate laboratory, the students can also carry out this activity in the preparatory phase of the training. Acquiring the measuring skills and developing the ability to measure is a little more complex student's activity, gaining experience and practising, developing the psychomotor abilities may alternate here. This is, in any case, an independent activity or done in smaller groups (of 2 to 3 persons), and students can learn from one another, so this is also suitable for cooperative (collaborative) learning. However, these classes in the laboratory or in the field require some experience in the use of the instrument, and some knowledge of the theory of measuring and other technical knowledge. The course is mostly classically deductive, that is, from the general knowledge towards the individual, particular experience, because the laws and rules are verified with measurements. The third type or 'stage' is the measurement activity that includes diagnosing, in which the developed measuring abilities must be applied independently in a specific task. Here, the knowledge about measuring and the instrument and the ability to use it are on such a level that the operations help to explore the measuring task, the problem (analysis, determining the composition, malfunction etc.) in a 'routine' way but consciously and expediently. This is necessary in the case of a great number of environmental problems or measurements, and therefore, the environmental technicians' competence must be developed to this 'level'.

This way, also the method competence areas in Table 3 can be developed in course of the measurements. [17]

In a pedagogical-methodological aspect, one must strive for this 'multiple-stage' development of measuring competence to be attained - in harmony with the competence areas and levels described in the vocational and examination requirements. The laboratories and instruments of the given school do not always render this possible, which is also verified by our research experience. However, one must strive for the gradual development of the measuring competence from a didactic aspect to become possible through the expedient shaping of the conditions. This is not always a question of tools, instruments and laboratory but, much rather, that of the organization of learning, combining the methodical variants and applying them with modern ICT.
Evaluating the students' achievements during measuring is more complex and it has other kinds of solutions and characteristics from a methodological aspect than evaluation in other subjects or modules. This complexity derives from the combination of the knowledge of principles and theory, and practical applications and realizations. Since the performance of the specific measurements requires checking the students' knowledge of the object of the measurement, of the operational principle of the instruments and of the methods of measuring, and, further, their activity during measuring and also the documents showing the results of the measurement. These constitute also the object of marking or evaluation. During our research, we could observe that, among these three components, mostly the evaluation and checking during the measuring activity does not happen or it is not reflected in marking. However, it would be important from the point of view of formative evaluation since it could help to create the expertise in using the instruments, the routines and competence areas, which have a developing effect with the teacher's confirmation.

\subsubsection{The Objective and Fields of Research}

We describe the research on the basis of Márföldi Anna's Doctoral Thesis. [18] Its consultant was Dr. habil Lükö István.

The objective of the research was, on the one hand, to explore the measuring-related requirements and curricular content of the environmental qualifications of the OKJ, analysing the syllabi and the requirements. On the other hand, it was to examine the students' and teachers' teaching and learning conditions as to measuring technique, and their methodological aspects.

The objectives form a system of tasks that constitute research contents on diverging fields and scenes, using various methods. The following topic areas spring from these, just to list them:

- An analytic exploration of the system and requirements of the secondary-level environmental qualifications in the $\mathrm{OKJ}$

- The examination of how the environmental measuring technique appears in the modular system of environmental qualifications. How the content of this measuring technique is structured, what topic areas it has. 
- $\quad$ Studying the literature dealing with the theoretical background of measurements and instruments, the vocational activity, the types, and the classification and methods of analytical measurements

- Studying the characteristics of measurement as students' and teachers' activity, within the general pedagogical-didactic context of the experimenting, measuring activity, empirical learning and project work.

- Countrywide survey of the instruments of schools teaching environmental measuring technique, empirical study related to the students' and teachers' activity at three chosen schools. (Applied methods, application of ICT, use of textbooks, motivation.)

\subsubsection{Questions and Hypotheses}

Some questions:

- Does the digital kit help the comprehensive preparation of the students? (not only in measurements and during evaluation but also when applying the techniques of archiving, documenting and presenting)

- What didactic methods do teachers apply in course of practice with instruments?

Hypotheses:

- Field measurements predominate over laboratory measurements

- The most frequent measuring tool of secondary schools is the measuring kit with rapid test.

- Besides textbooks, subject teachers also apply descriptions of instruments in foreign languages as technical literature to a great extent.

- When dealing with the theoretical topic areas of measurements, teachers also mention other topics besides the general presentation of the instrument and its application.

- When examining the environmental elements, the soil, the water and the air are dealt with predominantly.

- Based on the previous hypothesis, there is a considerable number of examinations of the soil and the water and, of meteorological measurements.

- Teachers mostly use traditional teaching methods but students like these less.

- Students like it if the teacher presents the use of the instrument.

- At secondary schools, interactive whiteboards are not applied in the theoretical education about the instruments but presenting the instruments live or with a computer are popular methods.

- When evaluating, the practical application prevails.

- Students learn most from the pictures in the textbook.

- Students want to be taught with interactive methods.

\subsubsection{The Methods of the Research}

We conducted our research with the help of the following explorative methods:

- analysis of documents to explore the theoretical background, about the didactic foundations of empirical learning through measuring, analysis of its methods and of the principles of measuring, of the trainings, syllabi and requirements of environmental occupations

- dealing with the literature on the theory and methods of measuring

- quantitative survey using questionnaires about the methodological aspects of measurements and the use of tools, applied in printed form, the questionnaires contained mainly closed-ended questions and were filled in anonymously by the members of the target group (students and teachers). Survey with questionnaires among teachers in three regions (South, Central and West Transdanubia) $n=$ $15+5$ persons. Survey with questionnaires among students, also in three regions $\mathrm{n}=225$ persons

- $\quad$ survey of efficiency about students' measurements using traditional instruments and the digital kit representing high technology, and about the results of their learning

- $\quad$ survey of efficiency about visualised pictures

After exploring the data, we used the following methods of processing:

- $\quad$ statistic analysis with the percental distribution of the data

- $\quad$ qualitative analysis, evaluating the teachers' and students' responses given on the questionnaires and to oral questions

\section{The Results of the Research}

In this section, we present only some details of the results of the research. Primarily the verification of the hypotheses marked with dark background is presented here.

\subsection{The Survey on the Types of Technical Literature used by Teachers}

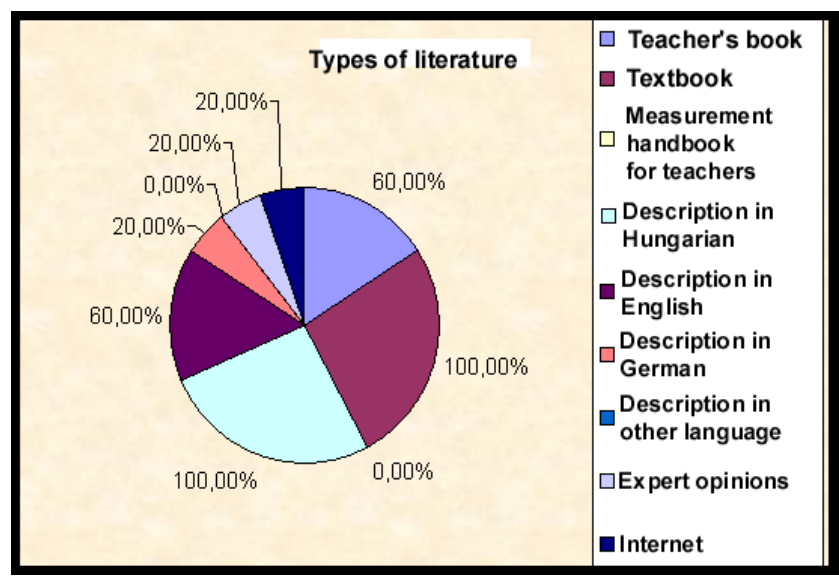

Diagram 1. The distribution of the use of various types of literature 
Among the topics of the teachers' questionnaire, the last question pertains to the types of used literature, the answers to which are shown in Diagram 1.

\subsection{The Survey on the Types of Technical Literature Used by Students}

In the students' survey, our first question was about the treatment of the theoretical knowledge of the instruments. It appears clearly from the answers in Diagram 2 that the teachers at the secondary schools of the three regions also lay stress upon the structure and operational principle of the instrument, besides its general presentation and application.

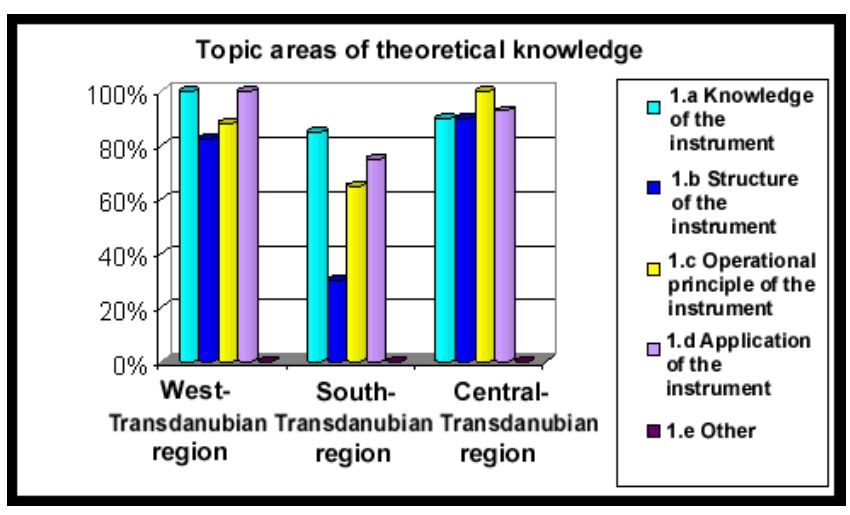

Diagram 2. The treatment of the theoretical knowledge of the instruments

The fifth question pertains to the methodology of the presentation or demonstration by the teacher in the theoretical lessons. The third diagram shows clearly that the teachers in the secondary schools of Central Transdanubia mostly apply Power Point projection (98\%), besides showing the instrument, sketch on the blackboard and transparency, while the teachers in South Transdanubia give preference to transparency $(100 \%)$. The teachers of the West Transdanubian region apply the showing of the instrument most often $(88 \%)$, which is attributable to the large number of their instruments.

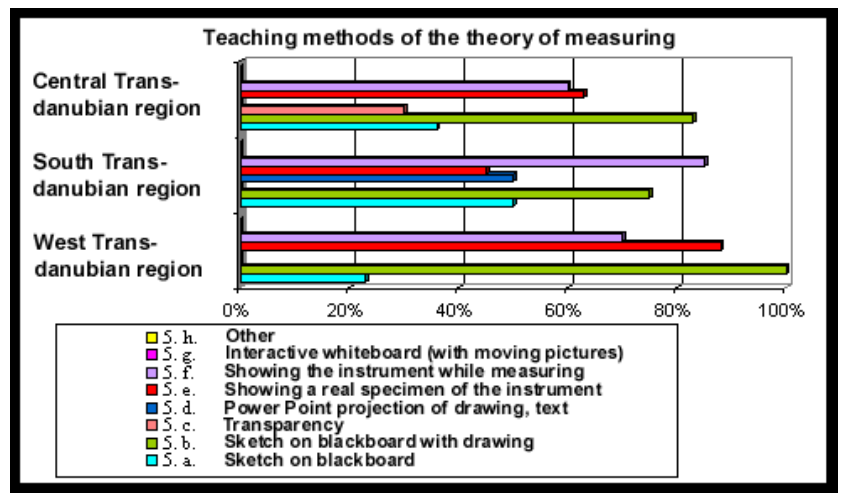

Diagram 3. The methodological variants of teaching the theory of measurement

\subsection{Investigation of Efficiency of Moving Pictures}

The process and method of the investigation:
The investigation of efficiency related to the visualization of the curricular content was embedded into the topic area of air filtration devices within the subject Environmental Technology. In two revision lessons before a test, we divided the class into a control group and an experimental group. The control group revised the content with the traditional methods, while the other group worked with the help of the visualised pictures. The tools, the processes and the notions were presented by them with the help of the pictures.

Among the results of the investigation, Diagram 4 shows the distribution of the answers given to the questions controlling the names of the components in the moving picture in.

As it can be seen, $25 \%$ of the experimental group achieved 11 points and $8 \%$ of them achieved 9 points.

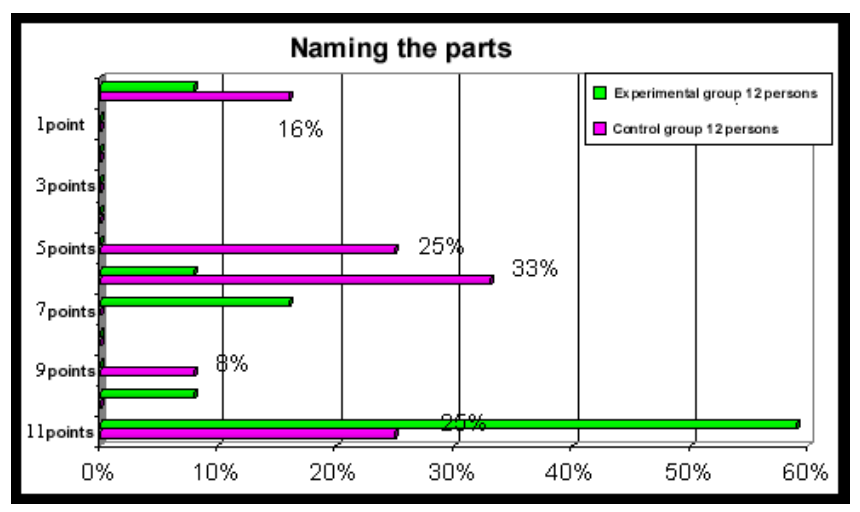

Diagram 4. The results of naming the parts

\subsection{Visualization of Curricular Content with the Help of Moving Pictures}

In order to investigate the efficiency of the learning with moving pictures, we had to develop a procedure and method, the essence of which is described as follows.

Earlier research on educational informatics proves that learning motivation and learning efficiency increases with the help of information and communication technology. [19]

At international surveys of knowledge and competence (PISA), good results are achieved by students from countries where multimedia solutions (moving pictures, sound, interactive software) are applied effectively. Thus, it has become obvious by the turn of the millennia that we must experiment with new pedagogical methods so that the virtual and real knowledge conveyed on digital devices and by word of mouth is attained in classrooms. [20]

One of the objectives of the research was to make the diagrams of the methods applied at lessons manageable, movable and interactive so that the students can deepen the acquired knowledge still more effectively and so that the teacher gets a new motivational tool. In Márföldi Anna's dissertation, the start screen, the process image during the working process and the final status of each module were elaborated for ten topic areas of measuring and environmental technology. [21]

We present one of these, the process image (middle phase) 
of the multimeter in Figure 1.

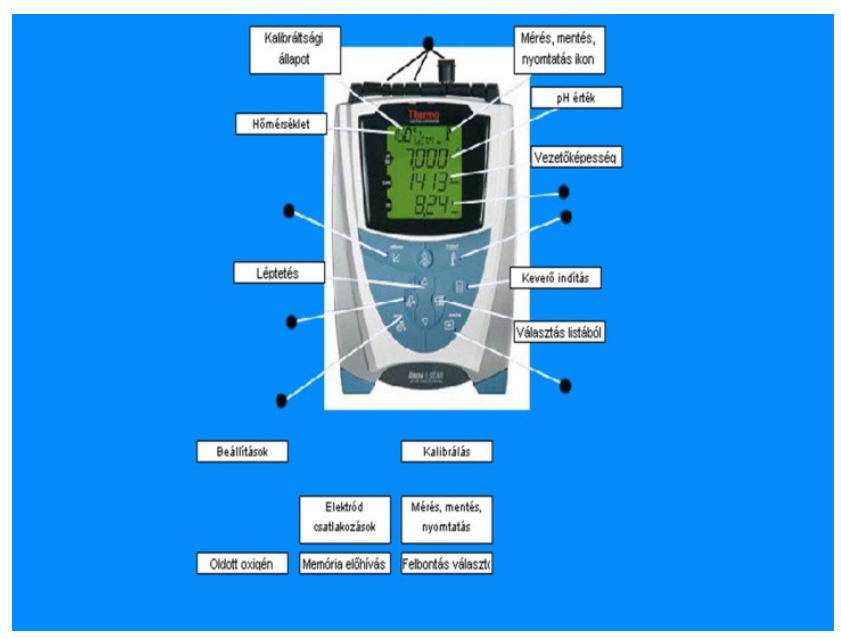

Figure 1. The process image of the multimeter

\section{Summary: Summing Up the Results of the Research}

During practical measurements, teachers mostly lay stress upon the basic chemical measurements. The examination of soil, water and air is significant during practice. Among the environmental parameters, the measuring of temperature, $\mathrm{pH}$, conductance and concentration appears in every school. Teachers' books, descriptions in Hungarian and English and the Internet help teachers most to get acquainted with the use of instruments. To sum up, we can state that the schools have a very little supply of instruments. The students get acquainted with a quite wide range of measurements. The hypotheses were verified through the results.

To sum up, we can state that the teaching of measurements in the vocational secondary schools of the three regions is on a high level also according to the students' opinions. The students want to have practice in groups, detailed and clear explanations from the teacher, a good supply of instruments and interactive acquisition of theoretical and practical knowledge. Students think that the use of ICT devices in both theoretical and practical lessons would be important for them, because traditional methodological solutions predominate in most schools, interactive whiteboards etc. are not used. Thus, the results of the research have proved the hypotheses.

Our suppositions have been verified, because the examination of the efficiency of the measuring with the multimeter proves that this instrument is advantageous to the students since the knowledge to be acquired, and the process and principle of measuring have become clearer and, what is the most important, so has the evaluation of the measuring data.

We could prove our hypotheses since the control group achieved fewer points than the experimental group - though the difference was only 10 to $20 \%$ - in the elements of knowledge, the explanation of the operation and naming the elements of the process. The investigation showed that the moving pictures help the ability to associate, the learning of the principle, parts and operation of the instruments, and further, they help theoretical education as motivation. The results of our investigation supported our hypotheses, since visualisation increased the speed of learning, helped faster acquisition and thinking, besides motivation.

\section{Acknowledgements}

I thank the American leader of the World Bank project, the expert Jef van Den Hurk, Sallay Mária and Dr. Gubán Gyula, leading officials of the Ministry of Labour.

I offer my thanks to my former students and colleagues, who participated actively and competently in the technical-professional establishment of the laboratory and in the elaboration of its pedagogical-methodological application. Most of all, I should mention the names of Tranta Károly, Petyus András, Dr. Orbay Péter and Hoczek László. Last but not least, I would like to thank Márföldi Anna, my former doctoral candidate, for her assiduous work of high standard, with which she contributed to the efficiency of the methodological research work of the department and the institute.

\section{REFERENCES}

[1] Biszterszky E. Hogy megújuljon a müszaki pedagógusképzés. (So that technical teacher training is renewed) Szakképzési Szemle, 1989/2.

[2] SALLAY M. Az ifjúsági szakképzés korszerűsítése. (The modernisation of the vocational education of youth) Programkörkép. Nemzeti Szakképzési Intézet, Budapest, 1997

[3] Gubán Gy. Tantervfejlesztés a szakközépiskolában. (Curriculum development in vocational secondary schools) In: Benedek András: Oktatáselméleti kérdések a szakképzésben. Müszaki Könyvkiadó, Budapest, 11-28. 1996

[4] Lükö I. Tartalmi és szervezeti átalakulások a szakképzésben (Changes of Content and Organisation in Vocational Training) Nemzeti Tankönyvkiadó, Budapest 2011

[5] Hoczek L. Laboratóriumi és terepi módszerek a környezetvédelmi képzésben. (Laboratory and field methods in environmental training) In: Eredmények és kihívások a szakmai tanárképzésben. NYME - Lővér Print, Sopron, 2002

[6] Lükő István - Csíkszentmihályi Péter (2005): Alapkészségek és kulcskompetenciák a környezeti kultúra fejlesztésében, különös tekintettel a designre Kutatási Zárótanulmány (Basic skills and key competencies in the development of environmental culture, especially the design. Research Study Final) NYME FMK Tanárképző Intézet- Alkalmazott Müvészeti Intézet Sopron, 2005-11-14 112 oldal

[7] Lükő István (1995): Bevezetés a szakmai módszertanokba, Egyetemi jegyzet. EFE Sopron, Introduction of professional 
methodology. Lecture notes. 6.p.

[8] Lükő I. Környezetpedagógia. (Environmental Pedagogy) Nemzeti Tankönyvkiadó, Budapest, 2003

[9] Colburn, A.: An Inquiry Primer. Science Scope, 23. 6. sz. 42-44. 2000

[10] Exline, J. (2004): Inquiry-based Learning: Explanation. Concept to Classroom. Wokshop: Inquiry-based Learning. http://www.thirteen.org/

edonline/concept2class/inquiry/index.html

[11] Prince, M. J. és Felder, R. M. (2006): Inductive teaching and learning methods: Definitions, Comparisons, and Research Bases. Journal of Engineering Education, 95. 123-138

[12] Lükő I. Oktatástan, (Didactics) Soproni Egyetem, Lövér Print, Sopron, 1998

[13] Kárpáti A. Informatikai módszerek az oktatásban. (Methods of informatics in education) In: A tanítás-tanulás hatékony szervezése. Educatio Kiadó, Budapest, 113. 2008

[14] Molnár Gy. New learning spaces? M-learning's, in particular the IPad's potentials in education INTERNATIONAL JOURNAL OF INTERACTIVE MOBILE TECHNOLOGIES 7:(1) pp. 56-60. (2013)

[15] Gabriels, W., Goethals, P. L. M. \& De Pauw, N. (2005): Implications of taxonomic odifications and alien species on biological water quality assessment as exemplified by the Belgian Biotic Index method. - Hydrobiol. 542: 137-150

[16] Lükő I. Környezetpedagógia. (Environmental Pedagogy) Nemzeti Tankönyvkiadó, Budapest, 2003, 212. p.

[17] Hoczek L. Laboratóriumi és terepi módszerek a környezetvédelmi képzésben. (Laboratory and field methods in environmental training) In: Eredmények és kihívások a szakmai tanárképzésben. NYME - Lővér Print, Sopron, 2002

[18] Márföldi A. A környezetvédelem pedagógiai módszertana a szakképzésben különös tekintettel a környezeti mérésekre (The pedagogical methodology of environmental protection in vocational training with special regard to environmental measurements) Doctoral Thesis, NYME Sopron 2010

[19] Kárpáti A., Molnár É. Kompetenciafejlesztés az oktatási informatika eszközeivel.(Developing competence with the devices of educational informatics) Magyar Pedagógia 2006.

[20] Kárpáti A. Informatikai módszerek az oktatásban. (Methods of informatics in education) In: A tanítás-tanulás hatékony szervezése. Educatio Kiadó, Budapest, 113. 2008

[21] Márföldi A. A környezetvédelem pedagógiai módszertana a szakképzésben különös tekintettel a környezeti mérésekre (The pedagogical methodology of environmental protection in vocational training with special regard to environmental measurements) Doctoral Thesis, NYME Sopron 2010, 113-114. pp. 